\title{
Cultural Heritage Preservation and Resilience in Urban Agriculture Through the Lens of Social Justice: A Case Study in Milan
}

\author{
Paola Branduini, Coline Perrin, Brigitte Nougarèdes, \\ and Elena Colli \\ INTRODUCTION
}

\section{Urban Agriculture and Cultural Heritage}

Urban agriculture is gaining increasing attention at a global level due to the introduction of food security and urban/rural regeneration policies (Mendes et al. 2008) and the growth of urban farms (Kaufman and Bailkey 2000; McMillan 2008). At the same time, other studies reveal the role of urban agriculture in maintaining traditions and cultural identity (Fairclough

\section{P. Branduini $(\bowtie)$}

ABC Department, Politecnico of Milan, Milan, Italy

e-mail: paola.branduini@polimi.it

C. Perrin • B Nougarèdes

UMR Innovation, French Institute for Agricultural Research Lab Innovation, Montpellier, France

E. Colli

Department of Sociology and Social Research, University of Milan-Bicocca, Milan, Italy

(C) The Author(s) 2020

A. Thornton, Urban Food Democracy and Governance in North and South, International Political Economy Series, https://doi.org/10.1007/978-3-030-17187-2_7 
2010), the role of landscape maintenance and the social role of community empowerment (Armstrong 2000; Wakefield et al. 2007). The rural landscape is a cultural good for the values of memory, identification and collective identity (Del Mastro 2005; Emiliani 1990; De Marchi 2000). Preserving and maintaining the landscape and promoting eco-sustainable agriculture is now an economic, environmental, social and cultural necessity (ELC [European Landscape Convention], ${ }^{1}$ WRL initiative, ${ }^{2}$ Branduini et al. 2016). Dealing with agricultural landscape as a heritage means considering the tangible and intangible aspects (Esbah et al. 2014; Branduini et al. 2016). Tangible heritage pertains to the material elements of agricultural landscape, to their historical authenticity and their physical permanence during the time. Intangible heritage pertains to the interpretation and significance attributed by people to places, techniques and skills that have enabled landscapes creation, to features dictated by economic and behavioural factors (Laviscio and Scazzosi 2015; Branduini et al. 2016); it acquires meaning through history, beliefs and traditions (Daugstad et al. 2006). Beside the scenic and spatial qualities, urban agriculture can be useful to preserve and enhance the historical characters of a landscape, according to environmental requests and community needs (Branduini et al. 2016).

In periurban European areas, agricultural heritage can be a public property and may concern large estate and a large part of the territory; public administration may directly manage the property or rent it to a farmer or a group of citizens (especially in periurban areas).

In Europe, several examples show an integration between urban agriculture and cultural heritage among common goods. In Geneva, the Canton owns an historic farm in the urban context (Budé farm), managed by a group of farmers: they produce vegetables following ancient techniques (cardoon whitening) and trade them directly in the farmers' market (Salomon Cavin and Mumenthaler 2015; Branduini 2016). In Seville, an association of urban gardeners took care of the restoration of an old farm (Miraflores farm), in the heart of the present public Parque De Miraflores, and spread their horticultural and cultural knowledge through workshop

\footnotetext{
${ }^{1}$ The preservation and enhancement of the whole landscape, ordinary and outstanding, rural and urban, in good and bad condition, is the fundament of the European Landscape Convention (2000), nowadays ratified by 38 of 47 member states of the Council of Europe.

${ }^{2}$ World Rural Landscapes (WRL) is an initiative launched by the International Scientific Committee on Cultural Landscapes (ICOMOS-IFLA) to foster worldwide cooperation in the study, management and protection of rural landscapes. http://www.worldrurallandscapes.org/.
} 
and courses (Branduini 2016). In Barcelona a consortium of municipalities manages the "Espaj de Gallecs", a set of agricultural lands taken during the 1970s, which continues to be managed by the same farmers to this day, famers who keep maintaining their buildings and fields and offer a place to relax with high historical and landscape quality (Maldonado et al. 2016).

\section{Heritage Preservation and Social Justice}

The policies of landscape and rural heritage preservation involve, in the first place, the monitoring of land use and building conditions, imposing specific rules and obligations that generally represent extra charges for landowners and farmers. Therefore, even if rural heritage preservation is recognised as a common value, it could become a heavy restriction, and may even be perceived as an injustice by some landowners or farmers, especially when they are unable to bear those costs. For example, in Fiesole-near Florence-the rules imposed for the preservation of olive groves, stonewalls and the agricultural purpose of large rural buildings have sometimes brought one to the abandonment of olive groves and the development of uncultivated land (Perrin 2013). That is the reason why heritage preservation policies generally need public support, which can be accessed under certain conditions.

In Italy, there is a wide presence of historical rural heritage of public property, mainly farmsteads owned by public administrations or inherited by social/assistance institutions, ${ }^{3}$ which are protected by the national law of cultural heritage due to their age and property (D.L. 42/2004). At the same time, the lack of public funds for its ordinary and extra-ordinary maintenance (Branduini 2005, 2011) led these public landowners to rent their rural properties (fields and buildings) on long-term agreements to the farmers (Di Donato et al. 2016; Perrin et al. 2017). Generally, while the maintenance of fields is in charge of the farmers, the rural buildings are in charge of the landlord, whether it is public or private property. In order to tackle the problems of maintenance presented above, the municipality of Milan (MM) and the Major Hospital (MH) - two of the main landowners of rural properties around Milan-have designed and implemented

${ }^{3}$ There are several examples in Italy of rural public properties: Ospedale Maggiore, ASP Golgi Redaelli, Pio Albergo Trivulzio, Stelline and Martinitt (Milano); Pia assistenza (Bergamo); Ospedale maggiore (Bologna). 
new forms of agreement for the renting of rural land and buildings, which have the aim to transfer the costs of maintenance to the farmers. This concerns not only the ordinary maintenance (which already was in their charge) but also the extra-ordinary interventions such as roof restoration or rehabilitation of buildings, which on the contrary have always been in charge of the landlord. This was realised with different strategies by the landowners, developing new forms of agreement with different levels of negotiation and participation during the decision-making process, which may originate feelings of injustice among actors.

Therefore, an analysis of these preservation policies in terms of social justice seems appropriate; the theories of justice allow to take into account the multiple principles of justice (Walzer 1983; Elster 1991) and to analyse in depth the social acceptability of public policies. In addition, the presence of academic studies about the social impacts of landscape preservation policies is still insufficient and there is the need of a stronger academic attention about social dynamics and policy durability. Some specific aspects of social justice have been part of the research design and analysis:

- Inter-generational justice (Soja 2010): long-term actions which are intended to produce equal-access conditions to resources among future generations

- Procedural justice (Rawls 1971): participation of all actors in decision-making processes;

- Spatial justice (Soja 2010): attention on spatial distribution of resources

- Capability approach (Sen 2010): the real capacities of a person to pursue their projects depend on both their personal capacities and the ones offered by the context (economic, legal, etc.)

- Capacity to aspire (Appadurai 2004): capacity to aim towards a better future with a positive attitude, instead of being negatively related to the past

Other than the theoretical framework of social justice explained above, we base the following research on the concept of resilience. There are many different definitions of resilience, which come from many disciplines and theoretical perspectives. We refer to resilience as the ability to absorb changes or disturbances (Handmer and Dovens 1996; Adger et al. 2005), to cope with potential impacts (Klein et al. 1998) and to survive (Nicholls and Branson 1998). In this chapter, thinking in particular about the 
capacity of the farmers to react positively to the new agreements (which we consider the "traumatic event"), we define resilience as the capacity of a system - be it an individual, a city or an economy - to deal with change and continue to develop (Landi 2012). This will help in focusing on how resilience is dependent on individual factors and to what extent there is a political responsibility to promote resilience (Morrow 2008), involving social justice dynamics which have consequences on the durability of the preservation policies and, as a consequence, on the quality of landscape preservation itself.

\section{Objective and Methodology}

The main aim of this chapter is to understand how to guarantee a longterm and equitable preservation of cultural heritage. As said in the introduction, preservation policies may have an impact on social equity issues. In the case of Milan, the problem is represented by the high costs that cultural heritage maintenance requires, which brought the main public landowners to implement new forms of agreement in order to transfer those costs to their tenant farmers, who reacted in very different ways. Why some of them had positive reactions, while others are risking abandoning activity and land? Our objective is to understand the elements that enable or hinder the resilience of the farmers in coping with these changes, and what are the consequences on heritage preservation.

Looking for the answers to these questions we analyse the dynamics of social justice embedded in the new agreements; we compare the different strategies implemented by the main landowners and the reaction of the farmers; we focus on what are the factors that can shape long-term and equitable preservation policies (Appadurai 2004; Nussbaum and Sen 1993; Ostrom 1990; Sen 2000; Sen 2010; Soja 2010).

To do so, we have implemented a qualitative methodology. Thirty semi-structured interviews have been carried out on a group of urban/ periurban farmers (ten tenants of the Major Hospital and ten of the municipality of Milan) and on ten officials from the involved organisations (public landowners, organisations for landscape management, union groups). The interviews aimed at investigating the profile of the local farmers (business strategies, maintenance interventions, history of the farm and future ambitions, opinions about new contracts) and the profile of the landowners' organisations and landscape management organisations (governance model, motivations that led to changes in contracts and 
dynamic of policy building). The interviews were transcribed and analysed following the three phases of qualitative research: segmentation, qualification and cross-cutting analysis of the data fragments based on the research aims and objectives (Cardano 2011; Kaufmann 2004; Van Eemeren and Grootendorst 2004). Dynamics of social justice has been extrapolated through sentiment and discourse analysis of the transcriptions.

The chapter will follow some main steps: (1) the exposition of the research objective and methodology; (2) an overview of the Milan context and the description of the new forms of agreements, with a comparison between the different dynamics of social justice; (3) the analysis of the barriers and enablers of the farmers' resilience in the process of facing the new agreements; (4) a categorisation of the farmers' different strategies and the influence on landscape preservation. As an outcome, we propose some policy guidelines, addressed to public landowners and public institutions, in order to contain the negative impact of preservation policies on social justice.

\section{The Milan Context}

The case of Milan has academic relevance for many reasons: it is representative of the cases of cities with a widespread historical rural heritage of public property to manage and maintain; at the same time, it is unique for its experimentation of new forms of tackling the problem of the costs and responsibility of the maintenance interventions with new forms of rural rental agreement, which have a global interest in order to understand their weaknesses and strengths and elaborate on their potential transferability/ replicability in other cities. Furthermore, Milan became a global benchmark for food and rural policies after hosting the World Expo 2015 with the theme "Feeding the planet, energy for life".

Since 1960, at a global level, three different kinds of policies have been implemented by public organisations in order to protect agricultural land and contain urban expansion: (a) public land acquisition and management, (b) regulation on land use (normative approach) and (c) incentive policies and education/information campaigns (Alterman 1997; Bengston, Fletcher, and Nelson 2004; Maruani and Amit-Cohen 2007). In Milan, the Rural Park South Milan has tried to integrate the normative approachwith prescriptions about intervention on landscape addressed to the 
professionals (Territorial plan of the Park $2000^{4}$ ) —and information/education campaigns for the citizens (fairs, information points, farmer markets). The municipality has changed its policy from passive protection of rural heritage to more proactive interventions, encouraging the farmers to join in a district (Agricultural District of Milan, regulated by the Region) and to invest in agricultural diversification. In addition, these farmland protection policies are implemented in a multi-level governance framework that includes authorities at different levels (region, metropolitan area, municipality, farmers' associations). ${ }^{5}$ The municipality also supported Expo 2015 and the signature of the Milan Charter (Urban Food Policy Pact $\left.^{6}\right)$.

In Milan, the utilised agricultural area is 66,461 ha, in a total metropolitan area of 157,500 ha with 3.2 million of inhabitants. The sector of animal production represents $60 \%$ of the GSP, ${ }^{7}$ and cereals $(21 \%)$ dominate vegetal production $(40 \%)$ (corn, rice), followed by forage rotations and permanent meadows (irrigated meadows). ${ }^{8}$ The farms are 592 in total; the average surface is 48 ha and the surface of a rural building can vary between 1000 and 5000 square metres. ${ }^{9}$ Families that live and work in the same rural building since generations compose the farm enterprises interviewed. ${ }^{10}$ In these farms, in addition to traditional agricultural activities, it is frequent to see complementary activities, especially near the urban centre: there are profit activities (e.g. agritourist, direct selling, horse boarding, petting zoo, renting spaces for ceremonies, etc.) and non-profit activities (cultural events in collaboration with public institutions or associations, local fairs, markets, community gardens, open days, etc.) (Fig. 1).

\footnotetext{
${ }^{4}$ Available at http://www.cittametropolitana.mi.it/parco_agricolo_sud_milano/territorio_ e_pianificazione/piano_territoriale_di_coordinamento.html.

${ }^{5}$ Milano Metropoli Rurale, based on the agreement "Accordo Quadro di Sviluppo Territoriale" (Agreement Framework for Territorial Development). Available at http:// www.agricity.it/politiche-e-strategie-del-comune-di-milano/.

${ }^{6}$ Ibidem.

${ }^{7}$ Gross saleable product.

${ }^{8}$ ISTAT, $6^{\circ}$ censimento agricoltura 2010, www.istat.it.

${ }^{9}$ Data available at http://www.cittametropolitana.mi.it/parco_agricolo_sud_milano/ territorio_e_pianificazione/il_territorio_in_cifre.html.

${ }^{10}$ With an average of 56 years of presence of the family in the farm. Five between 0 and 29 years; 4 between 30 and 59 years; 6 between 60 and 90 years; 4 over 90 years. The longest period registered was 127 years.
} 


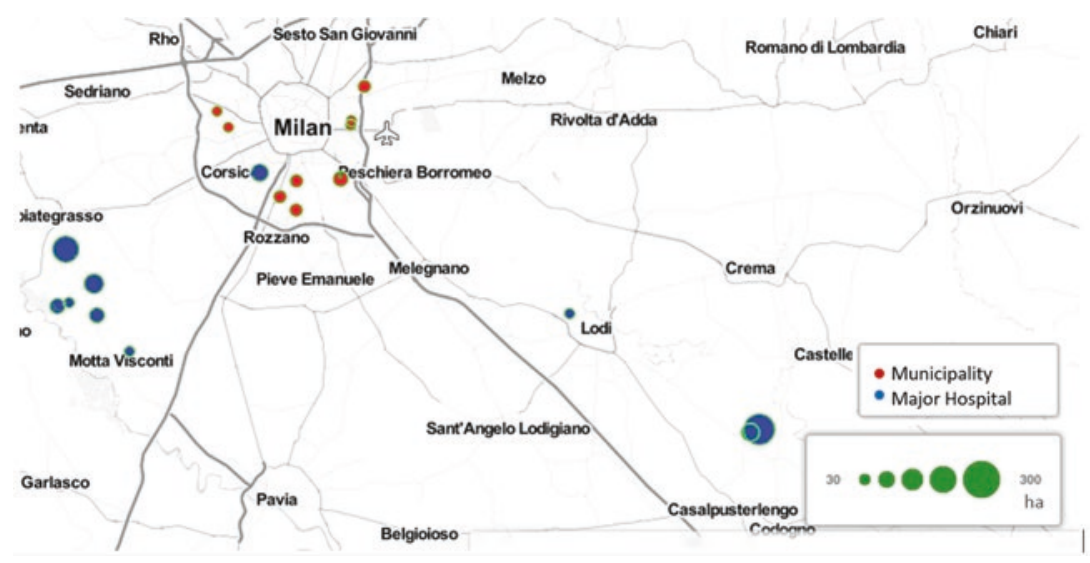

Fig. 1 Farm dimensions and distribution on Milanese territory. Created by Elena Colli on (C) CARTO. Map tiles by Stamen Design, under CC BY 3.0. Data by OpenStreetMap, under ODbL. Map title on CARTO: "Dimension". Basemap available at: https://elenacolli42.carto.com/builder/b4alb4d8-b7ff-1le5-a5fc0e98b6l680bf/embed

\section{The New Agreements of the Municipality of Milan and the Major Hospital}

Farm renting in Italy represents $42 \%$ of the utilised agricultural area; in Lombardy it is $65 \% .{ }^{11}$ The national law about farm renting (law no. 203, $3 / 05 / 1982$ ) states that (a) the minimum period of renting should be 15 years; (b) compensations should be given in case of maintenance work or interventions on the building; and (c) at the end of the agreement, the tenant farmer has the right to claim for priority in case of a new agreement. Every variation on the contract duration or obligations imposed by the national law are allowed by derogation (defined by Art. 45), and must be discussed and approved by the landlord, tenants and their representative organisations (landowners' union; farmers' union). The mechanism of derogation has been used by both the municipality and the Hospital to shape new agreements. It represents a good tool for the protection of the farmers' rights because it implies a negotiation process and constructive conflict management (Masia 1992); it restrains the dominant role of landlords and confers flexibility and dynamism to land management (Pirani

\footnotetext{
${ }^{11}$ Source: ISTAT data elaborated by Federazione Nazionale della Proprietà Fondiaria.
} 
et al. 2016), giving the opportunity to shape an agreement which reflects the visions of both farmers and landlords in a common project.

In Milan, starting from 1920, the municipality became owner of many rural lands because of the urbanisation processes. ${ }^{12}$ Since 2011 , it started to propose policies for rural development and regeneration, which included the enhancement of rural buildings (cascine). The agreement renewal comes with these policies, with some crucial innovative elements, in particular: (a) the introduction of extra-ordinary maintenance in charge of the farmers, with a deduction of those investments on the annual renting fee, and (b) the possibility to sub-locate the unused spaces of the building to complementary activities related to agriculture (agritourist, petting zoo, direct sale of local products, etc.). The extra-ordinary maintenance of the building includes all the interventions of renewal and restoration: for example, substitution of structural parts (roof, walls) or integration with new hygienic and technological services (wiring, sewerage, etc.). ${ }^{13}$

As mentioned before, the Major Hospital is one of the main landowners in Milan. ${ }^{14}$ In its case, the costs of extra-ordinary maintenance were already in charge of the farmer, in exchange of a very long-term agreement (30 years) with a lower rental price. This turned counterproductive due to a lack of proper monitoring of tenants' obligations fulfilment. Therefore, the duration of agreements was reduced again to 15 years, adding a strict system to monitor maintenance obligations, which were the obligation for the farmers to present a maintenance plan (in order to compensate the deficiencies accumulated during previous years) and to meet that schedule year per year, pain of agreement revocation (Table 1 ).

We investigated the level of collaboration between farmers. The results suggest a positive attitude, which breaks the classic stereotype of the isolated and competitive farmer, and allude to a new path of collaboration between the farmers instead of competition, boosted by the creation of the Agricultural District. This is particularly true among the farmers of the municipality (Fig. 2).

\footnotetext{
${ }^{12}$ Today, 2910 ha within the municipal borders are dedicated to rural activities, among which 550 ha owned by the municipality; the farms are 62, among which 11 with rural activities (Casale 2016).

${ }^{13}$ The costs incurred by the tenants of the Major Hospital for all the extra-ordinary maintenance interventions started since the contract renewal ( 60 new contracts in 10 months) is $€ 1,875,966$. Source: http://www.fondazionesviluppocagranda.it/.

${ }^{14}$ The Major Hospital manages 8500 ha of agricultural land and 100 rural buildings within the province of Milan, Lodi and Pavia. It represents the $1 \%$ of total agricultural area in the region of Lombardy. Source: http://www.fondazionesviluppocagranda.it/.
} 
Table 1 Comparison between municipality and hospital

\begin{tabular}{|c|c|}
\hline Old agreement & New agreement \\
\hline \multicolumn{2}{|l|}{ Major Hospital (MH) } \\
\hline Until 1980 & - 15 years \\
\hline $\begin{array}{l}15 \text { years; extra-ordinary maintenance } \\
\text { in charge of the landlord }\end{array}$ & $\begin{array}{l}\text { - Extra-ordinary maintenance in charge of } \\
\text { the tenant }\end{array}$ \\
\hline Between 1980 and 2010 & - Increase of rental price according to current \\
\hline $\begin{array}{l}30 \text { years; extra-ordinary maintenance } \\
\text { in charge of the farmers and lower } \\
\text { rental prices }(€ 313 / \mathrm{ha})\end{array}$ & market values $(€ 800 /$ ha $)$ \\
\hline \multicolumn{2}{|l|}{ Municipality of Milan (MM) } \\
\hline Until 2015 & After 2015 \\
\hline - 15 years & - 30 years \\
\hline $\begin{array}{l}\text { Extra-ordinary maintenance in } \\
\text { charge of the landlord }\end{array}$ & $\begin{array}{l}\text { Extra-ordinary maintenance in charge of } \\
\text { the farmers, with a deduction of that } \\
\text { investment on the annual renting fee } \\
\text { - Possibility of sub-location of the unused } \\
\text { space to other agriculture-related activities }\end{array}$ \\
\hline \multicolumn{2}{|c|}{$\begin{array}{l}\text { Elements in common between the two landowners } \\
\text { - Extra-ordinary maintenance in charge of the farmers } \\
\text { - Better monitoring system on the execution and quality of the interventions } \\
\text { - Obligation to present and accomplish a maintenance plan } \\
\text { - General re-establishment of the governance structure of both organisations }\end{array}$} \\
\hline
\end{tabular}

\section{Results And Discussion}

\section{Landowners' Strategies: Necessities and Dynamics of Justice}

Both organisations are aware of the high value of their properties and their responsibility on that heritage, which, however, is currently in precarious conditions and sometimes in a serious state of disrepair and neglect, as a consequence of bad policy choices and implementation. The need to change was due to the risk of collapse of buildings and the necessity to add value to the unused/under-used heritage. Both organisations followed some common steps: (a) recognition and analysis of the current buildings status; (b) re-establishment of the internal governance structure, in order to define specific bodies dedicated to farm renting management; (c) transfer of the responsibility of maintenance to the farmers; (d) elaboration of new forms of contract; (e) strengthening the presence and the control on their lands, with more attention on building conditions and interventions, 


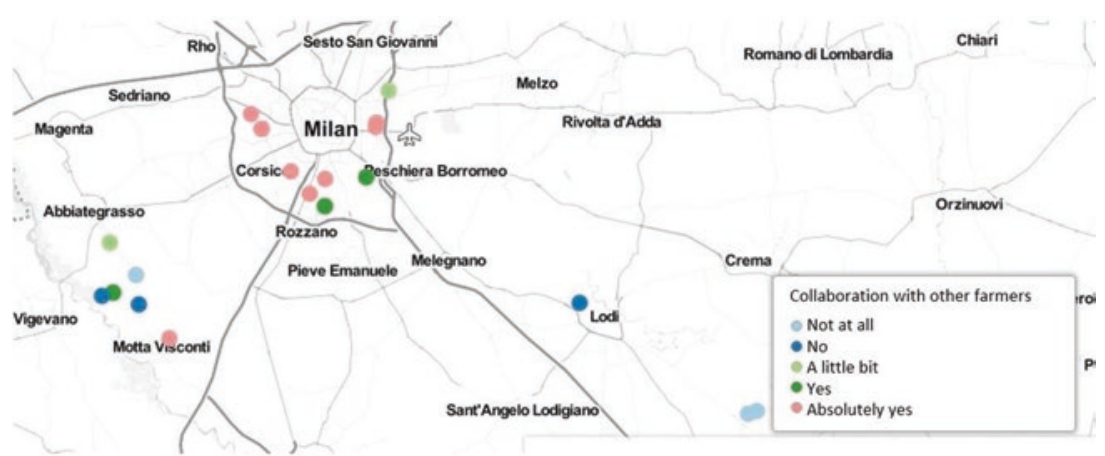

Fig. 2 Level of collaboration with other farmers. Created by Elena Colli on $($ ) CARTO. Map tiles by Stamen Design, under CC BY 3.0. Data by OpenStreetMap, under ODbL. Map title on CARTO: "Collaboration". Basemap available at: https://elenacolli42.carto.com/builder/67ced686-de9b-1le6-802b0e233c30368f/embed

intensifying the dialogue with the farmers, which had been neglected for many years.

After the analysis of the different strategies carried out by the landowners in terms of social justice, it is possible to define some crucial points:

1. Capabilities: the municipality has "bet" on the farmers' capacities; the innovative elements of cost deduction and sub-location have the aim to put the farmers in the condition to develop. The Hospital, instead, had a more "punitive" approach:

- "Our farmers have always lived with a low rent, so why should they innovate? Among 100 farms, there is only 1 agritourism and 1 direct sell ... in such a wonderful place. Why? If you bave a low rent, you do not need to innovate [...] the world of agriculture is so retarded because it always benefit from protection policies. And if it's not stimulated". (MH official)

- "As long as agriculture is considered a weak activity, the challenge is to give it the legal possibility to become strong. If it becomes strong, we all will benefit from it”. (MM official)

2. Procedural justice: the negotiation process between landlords and tenants is crucial to shape an equitable agreement. During contract 
renewal, the municipality carried out with the farmers a long negotiation, shaping conditions acceptable from both parties; the municipality also supported the creation of an Agricultural District, which almost all MM farmers joined, and helped them to gain more bargaining power as a unique strong actor. On the contrary, the contract renewal for the Major Hospital farms followed a top-down approach.

- "I would like to show you all the contract drafts... so you can see from what we started!" (MM farmer)

- "It's something imposed by the landlord; so as a tenant either you accept, or you break the agreement". (MH farmer)

The motivations behind the policy changes of the municipality and the Hospital are in both cases the risk of degradation and collapse of their rural heritage: eventually, their strategy was to give the farmers the responsibility to make it profitable. Whilst the strategy may look the same, there are substantial differences in the implementation process, particularly in terms of social justice. On the one hand, the municipality carried out a process of empowerment of the farmers, with several tools (the possibility of sub-location, the deduction of investments) and the inclusion within the decision-making process, with the aim to obtain a mutual benefit on long term (add value to the buildings and land, maintaining the status of a common good). On the other, the Hospital limited the capabilities of the farmers and their voices, excluding them from the decision-making process with a top-down approach, proposing short-term solutions.

Concerning heritage preservation, it is important to say that the current crisis of the agricultural sector has put the farmers in a precarious condition, so it is difficult for them to deal with new additional expenditures. This leads to different reactions and business strategies from the farmers, who may fall back on abandoning livestock or less profitable crops, thus causing a significant change in the landscape and a damage to the quality of soil and the biodiversity.

\section{Barriers and Enablers of Farmers' Resilience}

The cross-cutting analysis of the farmers' interviews allowed the identification of some recurrent elements, which we will label as the barriers and the enablers of the farmers' resilience, considering their reaction to the 
new agreement conditions. The most common strategy to face the additional costs is to add complementary activities on the farm; but this is not always feasible because of the presence or absence of certain elements that emerged as recurrent during the cross-cutting analysis of transcript interviews:

\section{Visions about the role of the farmer}

In some cases, a sense of injustice emerged in connection with the new role of "restorer/landscaper" of the farmer: for the farmers, property preservation should not be their responsibility, as they have neither the competences nor the role: "We have to work ... I am not a real estate developer!" ( $\mathrm{MH}$ farmer). Furthermore, a conflict about the farm as a place of work versus a place of leisure emerged.

In some other cases, the farmer acknowledges his social and cultural/educational role (as a source of knowledge): "The farmer has to take a stand as an actor on the territory. So its importance on the territory can be acknowledged, and this gratification can motivate him to add complementary activities to the farm, and become a 'creator' of the territory" (MM farmer).

2. Family issues

In some cases, the lack of an heir who will run the business, ensuring the continuity of the family enterprise, discourages long-term investments. It is also about family support: diversification works effectively with the family-farm model, because otherwise the costs of employees would be unbearable. "When I first came here I was engaged and I had a life project. Now I'm alone and it's difficult to manage this [the farm and complementary activities]" (MM farmer).

In other cases, there is a "perfectly working" family model that runs the business: men in fields, women in administration/tertiary activities, other relatives in complementary activities. "The intention is to create a family-business. The petting zoo could be run by my wife and children, because diversification in agriculture allows your family to become part of the business" (MM farmer).

3. Relationship with the city

"We [the farmers] farm the land; the city uses it" (MM farmer).

Other times, urbanity is seen as an advantage, because it is a source of customers and provides good infrastructures: "We are $200 \mathrm{mt}$ from the bus stop, and near the highway. We are in the middle of a green beautiful relaxing area ... but two steps away from the city centre. So we opened a B\&B" ( $\mathrm{MH}$ farmer). 
"We have to take advantage of what we are: we are the farmers of Milan. It was once a curse; now it should be an opportunity". (MM farmer)

4. Social and spatial networks

Some farms suffer from spatial isolation that could bring them to social/economic isolation: distance from the city discourages diversification; distance from other farmers creates difficulties to cooperate, to be attractive and to share a sense of injustice with others. "The Agricultural District gathers all farmers of Milan ... but I am too far. I am alone. The other farmers are in the western or southern part ... there, they managed to do good things. But here ..." (MM farmer).

Some other farmers are very good in networking; they are open minded and able to build collaborations with other farms, looking at their neighbour as a potential support, instead of as an enemy: "There is solidarity between us. We help each other, even beyond the work or machinery issues ... And it's a rarity" (MM farmer).

5. Other issues

Other elements which hinder a resilient reaction from the farmers are as follows:

- Bureaucratic nightmare: the sluggishness of bureaucracy goes against the dynamism of market and financing processes. This causes the exclusion of the ones who have not enough competences and/or resources to pay private collaborators, which could help.

- Difficult access to financial support/public funds: the fact that the farmer is not the owner of the building causes difficulties in access to credit and finance; and they need high competences to participate in public funds calls (see above).

On the opposite, other elements which facilitate resilience are as follows (Fig. 3, Table 2):

- Entrepreneurial attitude: personal attitude to risk/experimentation, often encouraged by long-term contracts; good predisposition to the tertiary sector, which brings one to reinvent the under-utilised spaces with new purposes for market opportunities.

- Attachment to the place: the strong bonding with the place fosters the farmers to do their best in order to keep the transmission of the farm from one generation to another. 


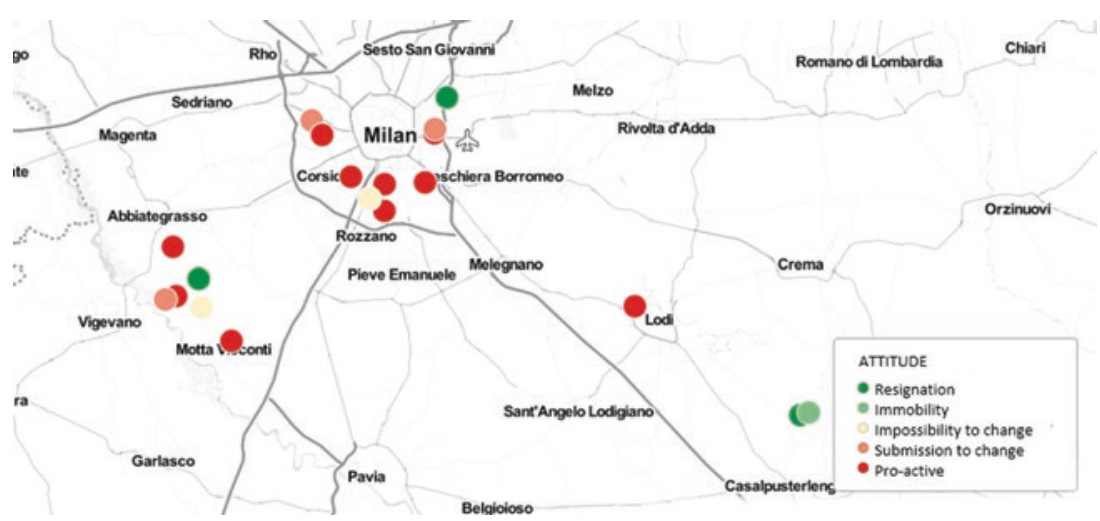

Fig. 3 Spatial representation of resilience. Created by Elena Colli on (C) CARTO. Map tiles by Stamen Design, under CC BY 3.0. Data by OpenStreetMap, under ODbL. Map title on CARTO: "Resilience". Basemap available at: https:// elenacolli42.carto.com/builder/16a58a12-de7c-11e6-ba4d-0ee66e2c9693/ embed

Table 2 Barriers and enablers of resilience

\begin{tabular}{ll}
\hline Barriers & Enablers \\
\hline - Farmer $\neq$ urban actor & - Farmer = urban actor \\
- Lack of family support & - Support of the family \\
- Spatial/social isolation & - Networking abilities \\
- Bureaucracy/financial access & - Entrepreneurial attitude \\
- Conflict with urbanity & - Attachment to the place \\
&
\end{tabular}

\section{Farmers' Strategies}

How do the farmers react to these changes? What strategies have they put in place? From the analysis of the results, two opposite profiles emerged (Table 3 ) as result of a combination of the elements examined in the previous paragraph.

These profiles are present transversally in the farmers from both the municipality and the Major Hospital. Also, other combinations of elements may shape some intermediate situations, on a scale from 0 (resignation) to 4 (proactivity): 
Table 3 How are the farmers reacting to the new contracts?

\begin{tabular}{|c|c|c|}
\hline & Characteristics & Elements \\
\hline Resignation & $\begin{array}{l}\text { No acceptance: "this is not my role" } \\
\text { - Refuse of multifunctionality } \\
\text { - Maintenance = burden } \\
\text { - Disillusion about the future } \\
\text { - Urbanity = disadvantage }\end{array}$ & $\begin{array}{l}\text { - Spatial isolation } \\
\text { - No family support (role division) } \\
\text { - No heirs } \\
\text { - No networks }\end{array}$ \\
\hline Proactivity & $\begin{array}{l}\text { "I make the changes become an } \\
\text { opportunity" } \\
\text { - Maintenance = investment in } \\
\text { the business } \\
\text { - Long term = planning } \\
\text { - Confidence in the future } \\
\text { - Urbanity = advantage }\end{array}$ & $\begin{array}{l}\text { - Willingness to diversify } \\
\text { - } \text { Role division among the family } \\
\text { - Heirs whors } \\
\text { - Networks } \\
\text { - Entrepreneurial attitude }\end{array}$ \\
\hline
\end{tabular}

1. Immobility: low-risk strategy; the new "role" is not completely rejected, but there is the preference to remain traditional.

2. Impossibility to change: there is the will to diversify activities and preserve the heritage, but there are not the necessary conditions (e.g. economic and/or family situation).

3. Constraint to change: there is entrepreneurial attitude and diversification of activities, but not for a real vocation; it is a forced choice imposed by the current conditions.

\section{Influence on Landscape Preservation}

In this framework, why can the agreements proposed by the municipality represent an innovation? The long-term contracts encourage the farmers to implement new commercial activities, which have cultural, touristic and productive impacts on the territory. The city starts to be considered as a source of customers, overcoming the old urban-rural rivalry (Branduini 2005). Therefore, new collaborations come up between public and private organisations and the farmers in order to satisfy the growing urban demand of rural services and leisure. This leads to the empowerment of the farmers, who now have more opportunities to dialogue and negotiate. The legitimation of sub-location opens the doors of entrepreneurial risk, giving the farmer more opportunities and motivation to diversify activities; 
the fact that maintenance interventions required from the contract go well together with investments in diversification activities (touristic, social, etc.) brings one to experiment new innovating elements within the contract.

Ultimately, what impact does these new contracts have on preservation and land use? The strategy of the municipality-with long-term contracts and possibility to sub-locate-prevents consumption of land because it encourages the reuse of existing buildings. On the other hand, these new policies are likely to impose considerable management costs on the farmers: some of them cannot find alternative solutions, so they abandon traditional agricultural productions; also, subsidies for preservation of traditional agricultural techniques are not sufficient to cope with the new maintenance costs incurred. Listening to the farmers and taking care of procedural justice during the decision-making process help to avoid consequences that fall on the quality of the commons, particularly the landscape.

If, on the one hand, the reconciliation of urban population with agriculture leads to the acknowledgement of the value of rural heritage (Branduini 2016), the combination of these two worlds' frequent contact between the urban population and the farmers generates conflicts that require institutional mediation (regulation, education and information campaigns).

\section{Conclusions}

This chapter analysed the implications of the new forms of rural rent agreements on the farmers' resilience and landscape preservation. In particular, the framework of social justice helped us to find the barriers and enablers of the farmers' resilience, analysing in depth the decision-making process and the role of policy and individual factors in determining positive or negative reactions to changes. Among the new agreements experimented in Milan, some innovations are detected in particular: the deduction of the investments costs, the possibility to sub-locate underused spaces of rural buildings, and the new forms of governance and negotiation between farmers and landowners. The new contracts aim to integrate urban and rural, through the empowerment of the farmer: he is a producer of food, maintainer of landscape, promoter of leisure and cultural activities, keeper of ancient knowledge and heritage to preserve and transmit to future generations. The farmer becomes a full actor of preservation policies; agriculture acquires a new dignity and a new role, 
dialoguing and integrating in the urban environment while keeping its productive vocation.

This agreement can be useful for all public organisations, which have to deal with the same problems of management and maintenance of wide public properties. It could be useful to understand how social justice dynamics can be crucial in enhancing the farmers' resilience, and consequently to understand how to implement decision-making processes and how to address specific policies to enhance the farmers' conditions (keeping in mind the barriers and enablers of resilience). It is important to highlight that the empowerment of the farmers-and the fact that they are in charge of maintenance-increases the awareness about heritage preservation as a common value and represents a mutual benefit for both the farmer (opportunity to develop with long-term planning) and the landlord (restoration of their heritage).

The analysis shows that different justice dynamics depend on elements that involve personal and context characteristics. The municipality recognises the farmers as urban actors, and gives them more instruments for resilience, understanding that this implies a mutual benefit. On the opposite, the Hospital, with a more top-down and punitive approach, had a negative impact on the farmers' resilience. Imposing new conditions without giving the instruments to face them, the capacity to react to these changes has been more difficult because it only relies on personal attitude and resources of the farmers. Therefore, the cross-cutting analysis of the capacity of the farmers to face the changes (resilience) shows that even without the best personal conditions and resources, a municipality farm can more easily cope with the new costs, thanks to more favourable contract terms.

\section{Policy Suggestions}

As a conclusion, there are proposed some policy interventions useful to maintain a balance between the needs of preserving the heritage of the landlords and the production needs of the farmers:

1. Networking and decision-making processes

- Support the network-building process of farmers (e.g. with agricultural districts), which gives them more opportunities to negotiate with public institutions, major weight in the decision-making 
process, more visibility to injustice feelings (which can become part of the activation processes) and less risk of isolation.

- Act on spatial isolation/risk of segregation by enhancing infrastructures and activities (internet connection, touristic itineraries, encourage machinery-sharing between farmers).

2. Long term: inter-generational justice and capacity to aspire

- Support long-term contracts-which allow long-term and ambitious planning (investments, diversification)—but integrated with a monitoring system for maintenance interventions and effective communication, to avoid risks of non-compliance.

3. Languages and bureaucracy

- Offer guidelines to tackle bureaucratic procedures, which can create conditions of inequality.

- Facilitate dialogue between farmers and landscape preservation organisations.

- Assume the role of guarantor in financial aid.

4. Information and education: supporting personal capacities

- Promote education and information programmes acting on entrepreneurial attitude (e.g. exposing best practices) and provide simple guidelines for preservation strategies and marketing strategies (networking, use of social media, etc).

The combination of these initiatives could expand the possibility of enhancing the farmers' resilience, helping them to see the contract changes as an opportunity to develop and innovate, and to improve their real capabilities in a more equitable context. At the same time, this could be an answer to the preservation needs of the landowners and to mitigate the risk of abandonment and mismanagement of their properties, with a positive impact on the landscape and preservation of rural traditions and heritage. 


\section{REFERENCES}

Adger, W. N., Hughes, T. P., Folke, C., Carpenter, S. R., \& Rockstrom, J. (2005). Social-Ecological Resilience to Coastal Disasters. Science, 309, 1036-1039.

Alterman, R. (1997). The Challenge of Farmland Preservation: Lessons from a Six-Nation Comparison. Journal of the American Planning Association, 63(2), 220-243.

Appadurai, A. (2004). The Capacity to Aspire: Culture and the Terms of Recognition. In V. Rao \& M. Walton (Eds.), Culture and Public Action (pp. 59-84). Palo Alto, CA: Stanford University Press.

Armstrong, D. (2000). A Survey of Community Gardens in Upstate New York: Implications for Health Promotion and Community Development. Health and Place, 6, 319-327.

Bengston, D. N., Fletcher, J. O., \& Nelson, K. C. (2004). Public Policies for Managing Urban Growth and Protecting Open Space: Policy Instruments and Lessons Learned in the United States. Landscape and Urban Planning, 69(2-3), 271-286.

Branduini, P. (2005). La multifonctionnalité du bâti rural dans le périurbain. Cahiers de la multifonctionnalité, 8, 133-145.

Branduini, P. (2011). Paesaggio e Agricoltura. La manutenzione del paesaggio agrario e l'innovazione in agricoltura. In L. Vallerini (Ed.), Piano Progetto Paesaggio Gestire le trasformazioni paesaggistiche. Temi e strumenti per la qualità (pp. 155-161). Pisa: Pacini Editore.

Branduini, P. (2016). Il patrimonio rurale nutre la città. Economia e società regionale, 2, 44-54.

Branduini, P., Laviscio, R., Scazzosi, L., Supuka, J., \& Toth, A. (2016). Urban Agriculture and Cultural Heritage: An Historical and Spatial Relationship. In F. Lohrberg, L. Licka, L. Scazzosi, \& A. Timpe (Eds.), Urban Agriculture Europe (pp. 138-147). Berlin: Jovis.

Cardano, M. (2011). La ricerca qualitativa. Bologna: Il Mulino.

Casale, F. (Ed.). (2016). Edifici rurali e biodiversità nel Parco del Ticino. Melzo: Parco Lombardo della Valle del Ticino e Fondazione Lombardia per l'Ambiente.

Daugstad, K., Rønningen, K., \& Skar, B. (2006). Agriculture as an Upholder of Cultural Heritage? Conceptualizations and Value Judgments - A Norwegian Perspective, in International Context. Journal of Rural Studies, 22, 67-81.

De Marchi, V. G. (2000). Laboratorio di urbanistica-Studi per la legge regionale. Bologna: Assessorato al Territorio Programmazione e Ambiente della regione Emilia Romagna.

Del Mastro, E. (2005). La tutela del paesaggio rurale: tendenze evolutive a livello nazionale e comunitario, La Aedon - Il Mulino, Fascicolo 2. 
Di Donato, B., Perrin, C., \& Cavallo, A. (2016). Strumenti di gestione dell'agricoltura urbana e periurbana: esperienze a confronto tra Roma e Montpellier, in Agriregionieuropa no. 44.

Elster, J. (1991). Local justice. European Economic Review 35(2-3), 273-291.

Emiliani. (1990). A. Emiliani, L'immagine del lavoro, in L'innovazione conservativa, Cento.

Esbah, H., Akyol, M., \& Steindl, M. (2014). Urban Agriculture: Implications on Istanbul Cultural Heritage. Journal of Environmental Protection and Ecology, 15(4), 1793-1800.

Fairclough, G. (2010). Complexity and Contingency: Classifying the Influence of Agriculture on European Landscapes. In G. Pungetti \& A. Kruse (Eds.), European Culture Expressed in Agricultural Landscape: Perspectives from the Eucaland Project. Palombi: Rome.

Handmer, J. W., \& Dovens, S. R. (1996). A Typology of Resilience: Rethinking Institutions for Sustainable Development. Industrial \& Environmental Crisis Quarterly, 9(4), 482-511.

Kaufman, J., \& Bailkey, M. (2000). Farming Inside Cities: Entrepreneurial Urban Agriculture in the United States. Cambridge, MA: Lincoln Institute of Land Policy, Working Paper.

Kaufmann, J. C. (2004). L'Entretien compréhensif. Paris: Armand Colin.

Klein, R. J., Marion, T., Smit, J., Goosen, H., \& Hulsbergen, C. H. (1998). Resilience and Vulnerability: Coastal Dynamics or Dutch Dikes? The Geographical Journal, 164(3), 259-268.

Landi, A. (2012). Il concetto di resilienza: origini, interpretazioni e prospettive. Sociologia Urbana e Rurale, 99, 79-98.

Laviscio, R., \& Scazzosi, L. (2015). Cultural Approaches Towards a World Rural Landscape Recommendation. In M. Di Stefano (Ed.), Heritage and Landscape as Human Values, Conference Proceedings. Napoli: Edizioni Scientifiche Italiane.

Maldonado, L., Alfranca, O., Callau, S., Giacché, G., Toth, A., \& Recasens, X. (2016). Barcelona. Outstanding Agricultural Diversity in a Dense and Small Urban Area. In F. Lohrberg, L. Licka, L. Scazzosi, \& A. Timpe (Eds.), Urban Agriculture Europe. Berlin: Jovis.

Maruani, T., \& Amit-Cohen, I. (2007). Open Space Planning Models: A Review of Approaches and Methods. Landscape and Urban Planning, 81(1-2), 1-13.

Masia, M. (1992). Il controllo sull'uso della terra. Analisi socio-giuridica sugli usi civici in Sardegna. Cagliari: CUEC Editrice.

McMillan, T. (2008). Urban Farmers' Crops Go from Vacant Lot to Market. The New York Times, May 7.

Mendes, W., Balmer, K., Kaethler, T. M., \& Rhoads, A. (2008). Using Land Inventories to Plan for Urban Agriculture Experiences from Portland and Vancouver. Journal of the American Planning Association, 74, 435-449. 
Morrow, B. H. (2008). Community Resilience: A Social Justice Perspective. CARRI Research Report 4. Miami: Community \& Regional Resilience Initiative (CARRI).

Nicholls, R. J., \& Branson, J. (1998). Coastal Resilience and Planning for an Uncertain Future: An Introduction. The Geographical Journal, 164(3), 255-258. Nussbaum, M., \& Sen, A. (1993). The Quality of Life. Oxford: Clarendon Press.

Ostrom, E. (1990). Governing the Commons: The Evolution of Institutions for Collective Action. Cambridge: Cambridge University Press.

Perrin, C. (2013). Le Foncier Agricole Dans Les Plans D'urbanisme: Le Rôle Des Configurations D'acteurs Dans La Production Locale Du Droit. Géocarrefour, 88(3), 183-194.

Perrin, C., Nougarèdes, B., Sini, L., Branduini, P., \& Salvati, L. (2017, October). Governance Changes in Peri-Urban Farmland Protection Following Decentralisation: A Comparison Between Montpellier (France) and Rome (Italy). Land Use Policy. https://doi.org/10.1016/j.landusepol.2017. 09.027.

Pirani, A., Gaviglio, A., Demartini, E., Gelati, M., \& Cavicchioli, D. (2016). Studio delle determinanti del valore degli affitti agrari. Potenzialità dell'uso di microdati e applicazione del metodo dei prezzi edonici. AESTIMUM, $69,131-151$.

Rawls, J. A. (1971). A Theory of Justice. Cambridge, MA: Harvard University Press.

Salomon Cavin, J., \& Mumenthaler, C. (2015). Agriculture Integrated into Urban Planning? A Challenge. In F. Lohrberg, L. Licka, L. Scazzosi, \& A. Timpe (dir.) (Ed.), Urban Agriculture Europe. Berlin: JOVIS Verlag.

Sen, A. K. (2000). Lo sviluppo è libertà: perché non c’è crescita senza democrazia. Milano: Mondadori.

Sen, A. (2010). The Idea of Justice. London: Royaume-Uni de Grande-Bretagne et d'Irlande du Nord, Etats-Unis d'Amérique, Canada.

Soja, E. W. (2010). Seeking Spatial Justice. Minneapolis: University of Minnesota Press. Retrieved from https://www.upress.umn.edu/book-division/books/ seeking-spatial-justice.

Van Eemeren, F. H., \& Grootendorst, R. (2004). Una teoria sistematica dell'argomentazione. Approccio pragmadialettico (tr. it., 2008). Mimesis, Milano.

Wakefield, S., Yeudll, F., Taron, C., Reynolds, J., \& Skinner, A. (2007). Growing Urban Health: Community Gardening in South-East Toronto. Health Promotion International, 22, 92-101.

Walzer, M. (1983). Spheres of justice. Basic Books: New York. 